\title{
Limits to grazing by herbivorous fishes and the impact of low coral cover on macroalgal abundance on a coral reef in Belize
}

\author{
Ivor D. Williams, Nicholas V. C. Polunin*, Vicki J. Hendrick \\ Department of Marine Sciences and Coastal Management, University of Newcastle upon Tyne, \\ Newcastle upon Tyne NE1 7RU, United Kingdom
}

\begin{abstract}
Widespread rises in the abundance of fleshy macroalgae on Caribbean reefs within the last 20 yr have variously been attributed to eutrophication, overfishing, or the 1983-4 mass mortality of the grazing sea urchin Diadema antillarum. However, none of those factors can satisfactorily explain why macroalgae are abundant today even on lightly fished mid-depth reefs in sparsely populated areas. Here we explore another explanation for rises in macroalgal cover on such reefs, namely that they are a side effect of declines in coral cover. We suggest that grazing by herbivorous fishes can exclude macroalgae from mid-depth reefs with high cover of hard corals, but that on lowcover reefs, the amount of space occupied by algae overwhelms the ability of grazing fishes to crop it down. We simulated the effect of $10 \%$ and $25 \%$ rises in coral cover by attaching 'pseudo-corals' (PVC tiles covered in a non-toxic anti-fouling coating) to reef substratum in $5 \times 5 \mathrm{~m}$ plots ( 3 groups: control, $10 \% \mathrm{~T}$ and $25 \% \mathrm{~T}$ ) on a $12 \mathrm{~m}$ deep forereef site in front of Ambergris Caye, Belize. Within $3 \mathrm{mo}$ of attaching tiles, macroalgae had declined by approximately $10 \%$ in $10 \% \mathrm{~T}$ plots and $25 \%$ in $25 \% \mathrm{~T}$ plots compared with control plots, and these new states persisted for the duration of the experiment (macro-algae averaging $38.0 \%$ in control plots, $28.7 \%$ in $10 \% \mathrm{~T}$ plots, and $13.6 \%$ in $25 \% \mathrm{~T}$ plots). Dramatic reductions in macroalgae may have made the $25 \% \mathrm{~T}$ plots more attractive to herbivorous fishes, as, in the later stages of the experiment, herbivorous fish biomass and acanthurid feeding rate were higher in those plots than in $10 \% \mathrm{~T}$ and control plots.
\end{abstract}

KEY WORDS: Coral reef $\cdot$ Grazing thresholds $\cdot$ Macroalgal dominance $\cdot$ Herbivorous fish $\cdot$ Caribbean Resale or republication not permitted without written consent of the publisher

\section{INTRODUCTION}

Within the last $20 \mathrm{yr}$ many Caribbean coral reefs have experienced dramatic shifts from coral-dominated to macroalgae-dominated states (Hughes 1994, Shulman \& Robertson 1996, Connell 1997, Rogers et al. 1997, McClanahan \& Muthiga 1998). Rises in macroalgal cover and the inability of reefs to return to their former states have been attributed to eutrophication (Lapointe 1997) or reduced grazing intensity as a consequence of overfishing of herbivorous fishes and the Caribbean-wide mass mortality of the grazing seaurchin Diadema antillarum in 1983-4 (Lessios 1988, Hughes 1994, 1996, Rogers et al. 1997).

${ }^{*}$ Corresponding author. E-mail: n.polunin@ncl.ac.uk
However, while there is ample evidence linking reduced herbivory and nutrient enrichment to local alterations in benthic community structure (Liddel \& Ohlhorst 1986, Levitan 1988, Morrison 1988, Carpenter 1990, Lapointe et al. 1992, Hughes 1994, Aronson \& Precht 2000a), there is a growing awareness that not all rises in macroalgal cover on Caribbean reefs are explicable in terms of those factors alone (McClanahan et al. 1999a, Aronson \& Precht 2000b). A clear example is the rise in macroalgal cover from $<5 \%$ to $>60 \%$ on forereefs at Carrie Bow Caye in Belize between 1980 and 1992 (Littler et al. 1987, Aronson et al. 1994). The remoteness of those reefs, the low fishing pressure in the locality (McClanahan et al. 1999a), and the fact that Diadema antillarum were scarce there even in 1980 (Hay 1981) implies that the macroalgal bloom

ㅇ Inter-Research 2001 


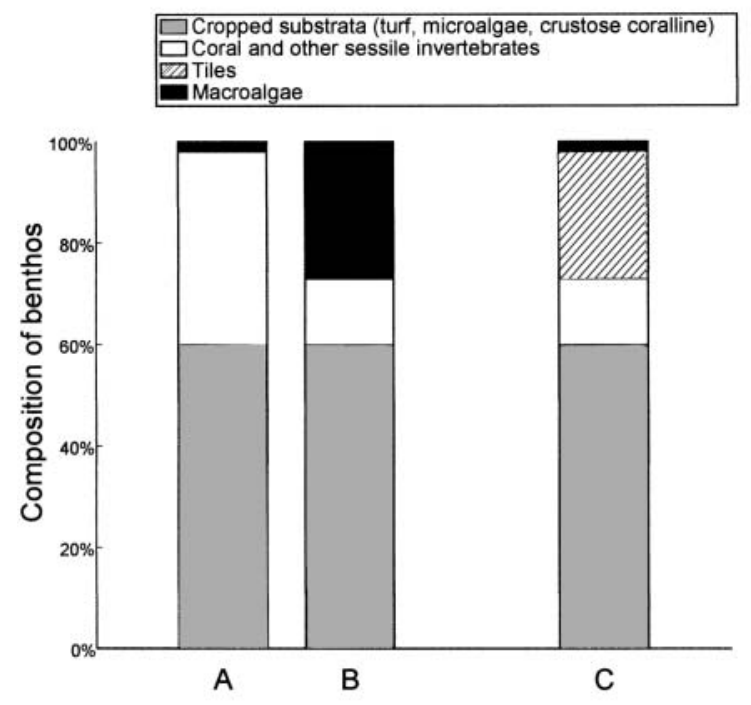

Fig. 1. Conceptual model of 'space-availability' explanation for macroalgal overgrowth of mid-depth reefs in the Caribbean: Column A represents reefs with high coral cover; Column B represents low coral-cover reefs; Column C represents the expected outcome of using 'pseudo-corals' (PVC tiles coated with non-toxic anti-fouling resin) to simulate the effect of a rise in coral cover on a low coral-cover reef

was driven by some factor other than nutrient enrichment, overfishing, or the $D$. antillarum mass mortality.

In a large-scale study of 12 to $15 \mathrm{~m}$ deep Caribbean reefs (Williams \& Polunin 2001), we suggested a possible alternative explanation, namely that the widespread abundance of macroalgae on surveyed reefs might have been, at least in part, a side-effect of recent declines in cover of hard corals, apparently caused by bleaching events and disease epidemics on an unprecedented scale (Williams \& Bunkley-Williams 1990, Shulman \& Robertson 1996, Aronson \& Precht 1997, McClanahan \& Muthiga 1998). The basis for our 'space-availability' model (Fig. 1) was that, although biomass of herbivorous fishes was positively correlated with cover of 'cropped substrata' (i.e., turf, microalgae, or crustose corallines), herbivorous fish populations were never large enough to 'crop down' more than about 50 to $65 \%$ of substratum, even though several surveyed reefs were within effectively managed marine reserves far from any obvious source of nutrient pollution (Williams \& Polunin 2001). We speculated that some combination of recruitment (Doherty \& Williams 1988), territoriality (van Rooij et al. 1996), availability of hiding places (Risk 1973, Roberts \& Ormond 1987), and predation (Hixon 1991) may generally limit herbivorous fish populations on mid-depth reefs to levels too low to prevent macroalgae from developing when very large amounts of substratum are colonised by algae. According to our model, on reefs with substantial cover of hard corals and other sessile invertebrates (approaching $40 \%$ or more), grazing by resident fishes, concentrated within a manageably small proportion of substratum, is sufficient to maintain benthic algal communities in cropped states and thus macroalgae are virtually excluded from such reefs (Column A in Fig. 1). However, hard coral cover is now frequently $20 \%$ or less on mid-depth Caribbean reefs (Aronson et al. 1994, Williams \& Polunin 2001), and therefore, in many locations, the amount of substratum occupied by algae apparently exceeds the amount that can be kept in check by grazing fishes alone, with the result that substantial stands of macroalgae have developed and persisted (Column B in Fig. 1).

The corollary of the space-availability model is that, at sites where there is now substantial macroalgal cover, resident fish populations would be able to exclude macroalgae were coral cover to increase. To test that model, we simulated the effect of rises in coral cover by attaching pseudo-corals (PVC tiles covered in a non-toxic anti-fouling coating) to reef substratum within experimental plots. Tiles attached to the substratum covered both cropped substrata and macroalgae, and so the immediate effect of tiling would be to reduce coverage of both those algal groups in tiled plots compared with control plots. According to our model, coverage of cropped substrata is a function of local herbivorous fish biomass, and coverage of macroalgae is effectively the amount by which the proportion of substratum occupied by algae exceeds the local cropping threshold (Fig. 1). Therefore, our expectations were that (1) cover of cropped substrata within tiled plots would return to levels similar to that found in control plots, but that (2) macroalgal cover in tiled plots would decline relative to control plots by amounts approximately equivalent to the amount of space occupied by the pseudo-corals (Column C in Fig. 1). Alternative explanations for any alterations in algal community structure might be that placing tiles within plots either attracted or repelled herbivorous fishes, or altered their feeding behaviour; we therefore also monitored biomass and grazing of herbivorous fishes to establish whether there were any such differences between control and treatment plots.

\section{METHODS}

Study location. This study was conducted at a $12 \mathrm{~m}$ deep forereef site in front of Ambergris Caye, Belize $\left(17^{\circ} 54.9^{\prime} \mathrm{N}, 87^{\circ} 56.8^{\prime} \mathrm{W}\right)$. The site appeared typical of the forereef at this depth for a distance of at least $10 \mathrm{~km}$ north and south of the selected study area, consisting of gently sloping low-relief spur and groove formations with hard coral cover of around $10 \%$ or less, and 
with abundant macroalgae, particularly Dictyota, Stypopodium and Lobophora species (Williams \& Polunin, unpubl. data). Fishing pressure in the vicinity of the site appeared to be extremely light, as at no time during the course of an 8 mo study did we observe any fishing activity or traps on the forereef within more than $1 \mathrm{~km}$ of the site. Diadema appeared to be effectively absent from mid-depth reefs around the study area, as we saw no Diadema at all in the course of nearly 300 dives there. The study site was within 1 of the larger areas which we had surveyed in 1997-8, and was selected as being representative of the several lightly fished reefs on which, we speculated, high macroalgal cover might be a side-effect of low coral cover (Williams \& Polunin 2001). Approximately 7 to 9 mo before the initiation of this experiment (between August and October 1998), the Belize Barrier Reef experienced 2 substantial disturbances: a major warming event (Aronson et al. 2000) and the near-miss of Hurricane Mitch. The immediate effects were dramatic in both cases: widespread coral bleaching and the near total removal of the visible portions of macroalgae from reef substratum (I. D. Williams pers. obs.). However, by the time we returned to the site in April 1999 to initiate this experiment, the $12 \mathrm{~m}$ deep forereef appeared to have returned to a state very similar to its pre-disturbance condition: coral cover was marginally lower in April 1999 than in April 1998 (8\% compared with $10 \%$ ), but macroalgal cover was almost identical ( $23 \%$ in April 1998, 22\% in April 1999) (Williams \& Polunin unpubl. data).

Experimental design. Pseudo-corals (henceforth 'tiles') were made from $1 \mathrm{~cm}$ thick PVC sheets cut into $15 \times 15 \mathrm{~cm}$ squares and coated with Ceram-Kote CuBR (Freecom Inc., Big Spring, TX), a US Environmental Protection Agency-approved non-toxic and nonsloughing anti-fouling resin coating that is embedded with copper flakes. Marine growth does not attach to copper and therefore algae were prevented from colonising substratum covered by these tiles.

In late April 1999, nine $5 \times 5 \mathrm{~m}$ experimental plots were established haphazardly along the $12 \mathrm{~m}$ depth contour on flat portions of solid substrate separated from each other by at least $25 \mathrm{~m}$. The corners of each plot were marked with stainless steel nails that were made more visible by attachment of small strips of pink nylon tape. The 9 plots were then randomly allocated into 3 treatment groups of 3: control (no treatment), $10 \% \mathrm{~T}\left(10 \%\right.$ of plot substratum $=2.5 \mathrm{~m}^{2}$, to be covered in tiles), and $25 \% \mathrm{~T}$ ( $25 \%$ of plot substratum $=6.25 \mathrm{~m}^{2}$, to be covered in tiles). Before the tiles were placed in the plots, benthos, herbivorous fish, and substrate rugosity were surveyed in each plot. Between 10 and 31 May 1999 approximately 1600 tiles in all were attached to the reef in the 6 treatment plots $(3 \times 10 \% \mathrm{~T}$,
$3 \times 25 \% \mathrm{~T}$ ). Tiles were attached directly onto the reef surface using stainless steel nails and were placed on areas of substrate previously occupied by algae (i.e., cropped substrata or macroalgae). Sediment was wiped off tiles at approximately monthly intervals to prevent it from building up sufficiently for algal colonisation. Tiles were initially copper coloured but within days of submersion, they changed to a light green.

Survey methodology. Benthos within plots was video surveyed 7 times: first as part of the preliminary surveys; then immediately after the tiles were fixed in experimental plots; and subsequently at 1 mo intervals for the duration of the experiment (5 mo ending in late October 1999). To reduce the impact of edge effects, only the central $3 \times 3 \mathrm{~m}$ portion of each plot was surveyed. Preceding the preliminary surveys, each of these $3 \times 3 \mathrm{~m}$ areas was divided into 12 permanent belt transects (each $3 \times 0.25 \mathrm{~m}$ ) using $2.5 \mathrm{~cm}$ stainless steel nails to fix the corners of each transect (i.e., 13 nails each $25 \mathrm{~cm}$ apart fixed along 2 opposite sides of the survey area). For each video survey, nylon line looped round the marking nails was used to temporarily demarcate these fixed transects. A diver swam slowly along the transects holding the camera perpendicular to the reef and using the lines bounding each transect as a visual reference to maintain the desired belt width and direction. In each survey, the entire $3 \times 3 \mathrm{~m}$ area was video surveyed by this method. Percentage cover of benthic organisms was recorded by replaying the video tape on a television with a clear plastic sheet containing 3 randomly located $1.5 \mathrm{~cm}$ circles placed over the screen. Analysis began with the first frame of each transect, after which the tape was advanced to the next non-overlapping position, at which point the tape was paused and that frame analysed, and so on. Data from the 12 transects were then pooled into a total for the plot. Around 20 frames were analysed per $3 \mathrm{~m}$ belt and, therefore, approximately 720 points were sampled per survey per plot $(12$ transects $\times 20$ frames $\times$ 3 points). A high quality digital video camera was used and hence very good resolution of single frames was obtained. Benthic organisms were recorded in the following functional categories: 'bare' substratum (i.e., no algae or other organism discernible from photograph but presumably colonised by microalgae), sand, hard coral (scleractinians), sponge, gorgonian, other invertebrates, crustose-coralline algae, turf (mixed species assemblages of diminutive algae), fleshy macroalgae (upright and anatomically complex algae with frond extension $>1 \mathrm{~cm}$ ), blue-green algae, and tile. Macroalgae were identified to genus.

Herbivorous fish (scarids, acanthurids, and pomacentrids) were censused at 4 time periods: before the tiles were attached, then 1,3 , and 5 mo after the tiles were placed. From 9 to 11 survey dives were conducted in 
each period, all of the plots being censused once during each survey dive. First, all scarids and acanthurids observed in or passing through a plot during a $3 \mathrm{~min}$ period were recorded by an observer remaining as immobile as possible approximately $3 \mathrm{~m}$ above the substrate at 1 corner of the plot. Species, length (estimated to nearest centimetre), and whether the fish took a bite within the plot were recorded for each fish. At the end of the 3 min period, an instantaneous count of pomacentrids was made by swimming slowly through the plot. For each fish censused, biomass was estimated using previously published mass-length relations for Caribbean fishes (Bohnsack \& Harper 1988). All survey dives were carried out between 09:30 and 15:30 h (approximately $3 \mathrm{~h}$ after sunrise and before sunset, respectively) and by the same observer. Accuracy of length estimates was achieved by initially practising with precut lengths of electrical cable of known length and then maintained by regularly checking estimates of length of benthic objects with a scale on the side of the recording slate. Before the start of this study, accuracy of length estimation was assessed using the methods of Polunin \& Roberts (1993). The mean error of estimates (30 lengths ranging from 5 to $38 \mathrm{~cm}$ ) was $<0.5 \mathrm{~cm}$ (Williams \& Polunin unpubl. data).

As part of the preliminary surveys, substrate rugosity of each plot was estimated by 6 to 14 randomly located transects in each plot, in each of which a $3 \mathrm{~m}$ long chain was carefully draped over the reef substratum and the straight line distance between the 2 ends measured. Rugosity was calculated by dividing the distance following bottom relief by the straight line distance between the 2 end points.

In the final month of the experiment (Month 5: October 1999), grazing rate (bites $\mathrm{min}^{-1} \mathrm{fish}^{-1}$ ) and pressure (bites $\mathrm{min}^{-1}$ plot $^{-1}$ ) of acanthurids and scarids were estimated by means of 9 to 11 replicate 20 min surveys plot $^{-1}$. Each of these grazing surveys had 2 components: an instantaneous estimate of abundance of acanthurids and scarids of length $5 \mathrm{~cm}$ and above inside the plot, followed by a $20 \mathrm{~min}$ period of observation in which bite rates of individual fishes were recorded by direct observation (a total of 180 to $220 \mathrm{~min} \mathrm{plot}^{-1}$ ). Fishes were selected haphazardly and then observed for a period up to $1 \mathrm{~min}^{\mathrm{fish}} \mathrm{H}^{-1}$. Species, length (estimated to the nearest centimetre), total number of bites, and length of time of observation were recorded for each fish. If the fish being observed moved out of the plot in less than $20 \mathrm{~s}$ then the bitecount for that fish was abandoned and the data were not used in the final analysis. Grazing pressure for each species was calculated separately for each plot by multiplying estimated mean abundance (number plot $^{-1}$ ) by mean bite rate (bites $\mathrm{min}^{-1}$ ) giving a figure for each species in terms of bites $\mathrm{min}^{-1}$ plot $^{-1}$.
Statistical analysis. To look for broad differences in benthic algal communities among the 3 treatments, algae were pooled into 2 functional categories: (1) macroalgae; and (2) the sum of the turf, bare, and crustose-coralline categories (hereafter 'cropped substrata'). Biomass of herbivorous fishes was pooled into 2 categories: (1) scarids; and (2) acanthurids. In preliminary testing of our methods we noted that although the majority of scarids and acanthurids in surveys appeared to be actively engaged in feeding, there were 2 groups of fishes that evidently covered much larger areas and fed considerably less frequently: terminal phase parrotfishes engaged in territorial defence; and small purposefully swimming groups apparently migrating up or down the reef. As our survey method involved counting all fishes in or passing through a plot during a 3 min period, we were concerned that these highly mobile fishes would be overrepresented. Therefore, to strengthen the association between the derived estimates of herbivore biomass and their likely grazing impact within plots, we excluded fishes that had not been observed to feed within the plot during the 3 min survey period. Pomacentrids made up less than $5 \%$ by biomass of all herbivorous fishes censused, and we therefore considered that their greatest impact on plot benthos would probably be in territorial defence. For this family, therefore, we pooled abundance data rather than biomass data.

There were sufficient grazing data for only 3 species (Acanthurus bahianus, Scarus isertii, Sparisoma aurofrenatum) for us to make meaningful comparison of bite rate or local abundance of individual species among experimental groups. To enable higher level comparisons, however, data on grazing pressure (bites $\mathrm{min}^{-1}$ plot $^{-1}$ ) were also pooled into totals by family and for both families combined.

Differences among the 3 experimental groups (control, $10 \% \mathrm{~T}, 25 \% \mathrm{~T}$ ) in benthic cover in each survey period, coral cover and rugosity before tiles were placed, and grazing rate in Month 5 were compared using 1-way ANOVAs ( 3 experimental groups, 3 replicate plots group $^{-1}$ ). We used nested ANOVAs (as there were multiple replicate fish counts for each plot in each survey) to test for differences among groups in herbivorous fish biomass or abundance at each survey period ( 3 experimental groups, 3 plots group ${ }^{-1}, 9$ to 11 replicate counts plot $^{-1}$ survey period ${ }^{-1}$ ). Where ANOVA indicated significant differences among groups for any variable, Tukey's test was used to identify significant pairwise differences between groups. Differences among groups in cover of benthic algae over the last 3 mo of the experiment (i.e., Months 3 to 5, August to October 1999) were tested using repeated measures ANOVAs (3 experimental groups, each consisting of 3 replicate plots sampled at 3 survey periods). Before 
ANOVA all data sets were tested for homogeneity of variance using Levene's test and normality using the Ryan-Joiner test. Where necessary (in 1 case only, pomacentrid abundance in Month 5) a square root transformation was applied to correct heterogeneity.

\section{RESULTS}

\section{Benthos}

Before the tiles were attached, there were no significant differences among experimental groups in rugosity, coral cover, macroalgal cover, or cover of cropped substrata (Table 1). All plots had low cover of hard corals (group means between 7.0 and $8.1 \%$ ), conspicuous macroalgae (group means between 21.5 and $27.0 \%$, consisting predominantly of Dictyota, Stypopodium, and Lobophora species), and substantial cover of cropped substrata (63.3 to $68.1 \%$ ).

The effect of placing tiles in treatment plots was that substratum previously occupied by algae was covered over with tiles and, therefore, immediately after the tiles were placed, mean cover of both macroalgae and cropped substrata was lower in tiled than in control plots (Fig. 2). Within 3 mo of placing the tiles, the difference in mean cover of cropped substratum between the control and tiled plots had declined to close to zero, and it remained negligible for the remaining 2 mo of the experiment (Fig. 2D). In contrast, differences between tiled and control plots in mean cover of macroalgae tended to increase until apparently reaching new equilibria after about 3 mo (Fig. 2B).

Over the final 3 mo of the experiment mean cover of cropped substrata was similar in the 3 experimental groups, namely (mean \pm SD) $51.7 \pm 5.7 \%$ in control plots, $50.8 \pm 4.8 \%$ in $10 \% \mathrm{~T}$ plots, and $51.8 \pm 4.7 \%$ in

Table 1. Mean \pm SD benthic cover rugosity, fish density, and biomass of the 3 plots in each experimental group (control: no treatment; 10\% T: $10 \%$ of plot substratum to be covered in tiles; $25 \%$ T: $25 \%$ of plot substratum to be covered in tiles) before attachment of tiles (data were pooled into averages per plot before calculation of mean and SD and therefore $n=3$ in each case). $p$ indicates results of 1-way ANOVA. * Significant difference at $\mathrm{p}<0.05$

\begin{tabular}{|c|c|c|c|c|}
\hline Experimental group & Control & $10 \% \mathrm{~T}$ & $25 \% \mathrm{~T}$ & $\mathrm{p}$ \\
\hline \multicolumn{5}{|l|}{ Benthos } \\
\hline Macroalgae (\%) & $21.5 \pm 6.4$ & $27.3 \pm 4.6$ & $27.0 \pm 6.9$ & 0.291 \\
\hline Cropped substrata (\%) & $68.1 \pm 5.7$ & $63.8 \pm 4.6$ & $63.3 \pm 2.8$ & 0.415 \\
\hline Coral cover $(\%)$ & $8.1 \pm 2.3$ & $7.2 \pm 1.1$ & $7.0 \pm 1.5$ & 0.714 \\
\hline Rugosity & $1.2 \pm 0.1$ & $1.2 \pm<0.1$ & $1.2 \pm<0.1$ & 0.585 \\
\hline \multicolumn{5}{|c|}{ Herbivorous fish (mean per $25 \mathrm{~m}^{2}$ plot) } \\
\hline Scarids $\left(\mathrm{g} 25 \mathrm{~m}^{-2}\right)$ & $279.7 \pm 164.4$ & $220.2 \pm 83.9$ & $311.2 \pm 142.4$ & 0.575 \\
\hline Acanthurids (g $\left.25 \mathrm{~m}^{-2}\right)$ & $159.4 \pm 34.8$ & $125.2 \pm 20.4$ & $109.3 \pm 59.6$ & 0.166 \\
\hline Pomacentrids (ind. $25 \mathrm{~m}^{-2}$ ) & $2.9 \pm 2.9$ & $2.4 \pm 0.2$ & $3.2 \pm 1.4$ & $0.034^{*}$ \\
\hline
\end{tabular}

$25 \% \mathrm{~T}$ plots. Mean macroalgal cover over the same time period differed substantially among groups (repeated measures ANOVA, $\mathrm{p}<0.001$ ), being highest in control plots (mean $38.0 \pm 6.1 \%$ ), approximately $10 \%$ lower in $10 \% \mathrm{~T}$ plots $(28.7 \pm 4.3 \%)$, and almost $25 \%$ lower in $25 \%$ T plots (13.6 $\pm 3.6 \%$ ) (Fig. 3 ).

\section{Herbivorous fish}

Before attachment of the tiles, there were no significant differences among the 3 treatment groups in terms of biomass of scarids or acanthurids (Table 1 , Fig. 4). Pomacentrid abundance did, however, differ slightly between plots intended for $25 \%$ tile cover and plots intended for $10 \%$ tile cover (Tukey's p $<0.05$, Table 1, Fig. 5). The absolute level of difference was, however, small (mean densities of 3.2 and 2.4 per $25 \mathrm{~m}^{2}$ plot, respectively) and neither group differed from the control group.

Scarid biomass was the largest portion of total herbivore biomass for all treatment groups at all time periods. Among the 3 treatments (control, 10\%T, 25\% and 4 survey periods (before and 1,3 , and 5 mo after tiling), biomass of scarids was $65.4 \pm 5.4 \%$ of total herbivore biomass, acanthurids constituted $30.1 \pm 5.2 \%$, and pomacentrids $4.5 \pm 2.6 \%$.

There appeared to be little short-term effect of the experimental manipulation on the larger herbivores, as 1 mo after tiles were placed, there were no significant differences among treatments in scarid biomass or acanthurid biomass (Fig. 4). However, there were significant differences among treatments in the later stages of the experiment: in Month 3, mean scarid biomass was higher in $25 \% \mathrm{~T}$ plots than in control plots (Tukey's p $<0.05$, Fig. 4) and in Month 5 acanthurid biomass was higher in $25 \% \mathrm{~T}$ plots than in control plots (Tukey's $\mathrm{p}<0.005$, Fig. 4).

More than $95 \%$ of all pomacentrids censused were of 1 species, Stegastes partitus, and no other species of pomacentrid was recorded in any plot at any time period at a density $>0.03 \mathrm{~m}^{-2}$ $\left(<1\right.$ plot $\left.^{-1}\right)$. Placing tiles had a clear and immediate effect on the abundance of these small pomacentrids (Fig. 5). From Month 1 onwards there were significant differences among treatments (1-way ANOVA, p < 0.005) and mean abundance per $25 \mathrm{~m}^{2}$ plot increased in $10 \% \mathrm{~T}$ plots over the course of the experiment from 2.4 to 15.6 , and in $25 \%$ T plots from 3.2 to 23.0 , compared with a small increase in control plots (2.9 to 5.8 plot $^{-1}$ ) (Fig. 5). 

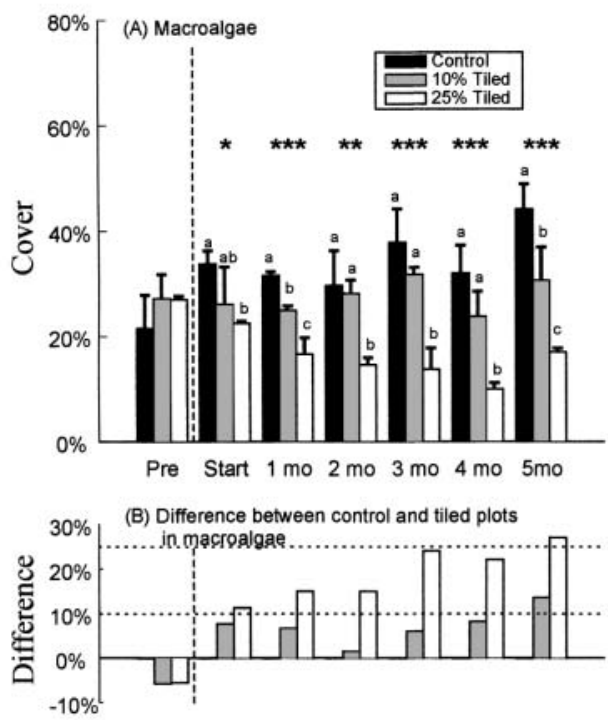
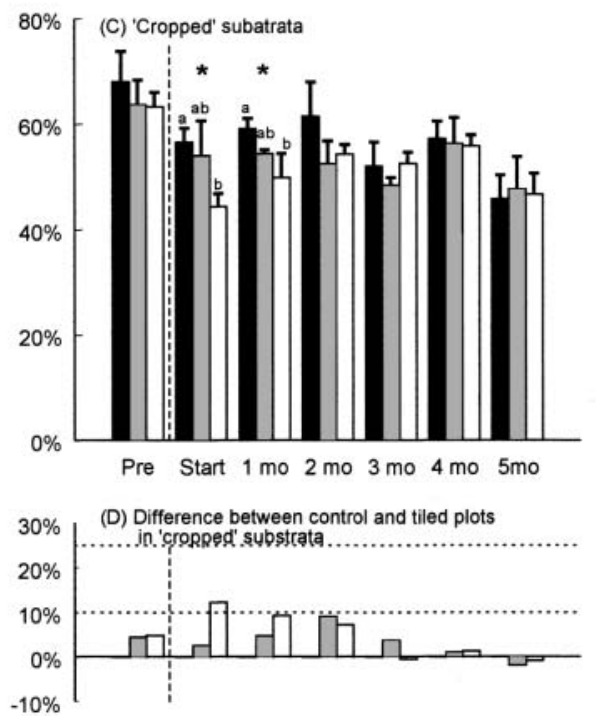

Fig. 2. Mean percentage cover of (A) macroalgae and (C) 'cropped substrata' in treatments at each survey period. Broken vertical line indicates the period in which experimental manipulation (i.e., fixing of tiles) occurred. 'Pre' indicates surveys before tiles were fixed, 'start' immediately after placing tiles, and ' $1 \mathrm{mo}^{\prime}$ to ' $5 \mathrm{mo}^{\prime}$ monthly surveys 1 to 5 mo after placing of tiles. Error bars indicate \pm 1 SD $\left(n=3\right.$ in each case). ${ }^{*} \mathrm{p}<0.05$; ${ }^{* *} \mathrm{p}<0.01 ;{ }^{* * *} \mathrm{p}<0.005$ significant differences among groups at any survey period. Letters attached to bars indicate groups that did not differ significantly at each time period (Tukey's pairwise comparisons). The differences between control and tiled groups within survey periods (mean of control group - mean of tiled group) are shown in (B) for cover of macroalgae and (D) for cover of cropped substrata

\section{Grazing}

There was no evidence that scarid grazing rates (bites $\mathrm{min}^{-1} \mathrm{fish}^{-1}$ ) or grazing pressure (bites $\mathrm{min}^{-1}$ plot $^{-1}$ ) varied among treatments at the time that we surveyed them (Month 5, Table 2). That was true not only for pooled family data, but also for the 2 species, Sparisoma aurofrenatum and Scarus isertii, for which there were sufficient data for meaningful species-level comparison. In contrast, acanthurid grazing pressure was significantly higher in $25 \% \mathrm{~T}$ plots than in $10 \% \mathrm{~T}$ and control plots (Tukey's p <0.05, Table 2). Bites by Acanthurus bahianus made up the great majority of acanthurid grazing (e.g., 70.5 out of a total of 77.4 bites $\mathrm{min}^{-1}$ in $25 \% \mathrm{~T}$ plots), and the higher grazing pressure of this species in $25 \% \mathrm{~T}$ plots than in $10 \% \mathrm{~T}$ and control plots (Tukey's p $<0.05$, Table 2) seems to have been driven by a combination of greater mean density and higher feeding rates (Table 2).

\section{DISCUSSION}

The effects of placing tiles to simulate rises in coral cover matched the predictions of our model almost exactly (compare Fig. 3 with Fig 1). Within 2 to 3 mo of tile attachment, there were no differences in cover of cropped substrata between control and tiled plots (Fig. 2C,D), but, over the same time period, macroalgal cover in $10 \% \mathrm{~T}$ and $25 \% \mathrm{~T}$ plots had declined relative to control plots by amounts approximately equivalent to the $10 \%$ and $25 \%$, respectively, of substratum occupied by tiles in those groups (Fig. 2A,B). Those new states then persisted for the remainder of the experiment. These results strongly support the idea of a local grazing threshold for herbivorous fishes, and, by extension, that herbivorous fishes may be able to exclude macroalgae from high coral-cover reefs but not from low coral-cover reefs, at least at the specific depth and location of this study.

An alternative explanation for declines in macroalgal cover in tiled plots is that fixing tiles in manipulated plots somehow made those areas more attractive to grazing fishes resident in the vicinity of the tiled plots and therefore artificially increased grazing pressure within those plots compared with control plots. We cannot completely rule out the possibility that our results were to some extent confounded in that way, particularly as biomass of her-

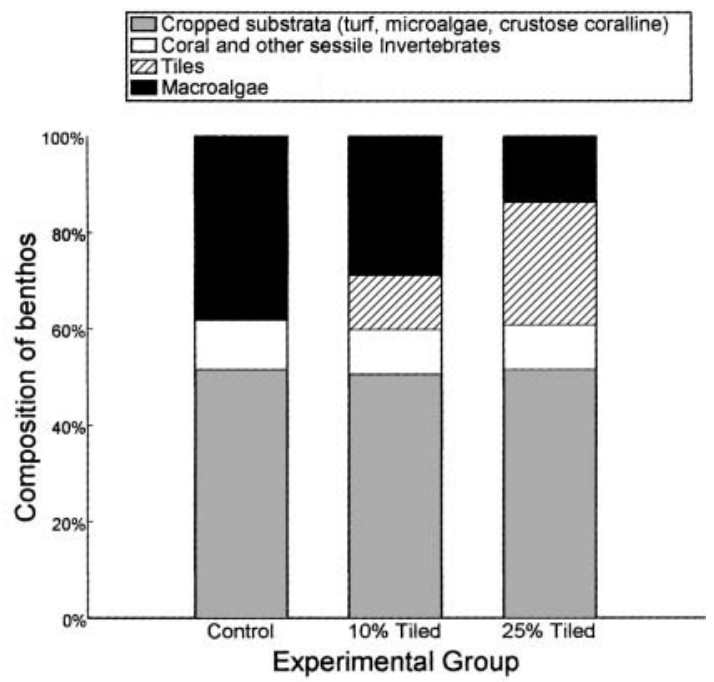

Fig. 3. Mean proportion of substratum occupied by macroalgae, 'cropped substrata', sessile invertebrates, and tiles in experimental groups during the last $3 \mathrm{mo}$ of the experiment (August to October 1999) 
Table 2. Mean $\pm \mathrm{SD}$ abundance, bite rate and grazing pressure of fishes $>5 \mathrm{~cm}$ in experimental groups in October 1999 (Month 5). $\mathrm{n}=3$ in each cases as data were pooled into means per plot before analysis. p indicates results of 1-way ANOVAs. When ANOVA indicated significant difference among groups, Tukey's test was used to determine significant pairwise differences (at $p<0.05$ ). ${ }^{*}$ : significance at $p<0.05$. C: control group

\begin{tabular}{|c|c|c|c|c|}
\hline Experimental group & Control & $10 \% \mathrm{~T}$ & $25 \% \mathrm{~T}$ & $\mathrm{p}$ \\
\hline \multicolumn{5}{|l|}{ Sparisoma aurofrenatum } \\
\hline Abundance $\left(25 \mathrm{~m}^{-2}\right)$ & $1.0 \pm 0.3$ & $1.0 \pm 0.1$ & $1.0 \pm 0.2$ & 0.963 \\
\hline Bite rate (bites min $^{-1}$ fish $^{-1}$ ) & $16.3 \pm 3.3$ & $13.0 \pm 1.9$ & $10.9 \pm 1.6$ & 0.083 \\
\hline Total bites(bites min $^{-1}$ plot $^{-1}$ ) & $15.8 \pm 5.3$ & $13.6 \pm 10.9$ & $10.9 \pm 1.6$ & 0.319 \\
\hline \multicolumn{5}{|c|}{ Scarus isertii } \\
\hline Abundance $\left(25 \mathrm{~m}^{-2}\right)$ & $1.9 \pm 0.5$ & $1.3 \pm 0.8$ & $2.0 \pm 0.8$ & 0.485 \\
\hline Bite rate (bites min $^{-1}$ fish $^{-1}$ ) & $34.9 \pm 5.8$ & $40.6 \pm 2.5$ & $38.7 \pm 0.7$ & 0.224 \\
\hline Total bites (bites min ${ }^{-1}$ plot $^{-1}$ ) & $65.7 \pm 21.5$ & $53.7 \pm 30.7$ & $77.8 \pm 30.0$ & 0.596 \\
\hline \multicolumn{5}{|l|}{ Acanthurus bahianus } \\
\hline Abundance $\left(25 \mathrm{~m}^{-2}\right)$ & $0.6 \pm 0.5$ & $0.9 \pm 0.2$ & $1.3 \pm 0.3$ & 0.123 \\
\hline Bite rate (bites min $^{-1}$ fish $^{-1}$ ) & $30.0 \pm 8.6$ & $47.5 \pm 5.2$ & $54.4 \pm 13.7$ & 0.054 \\
\hline Total bites (bites $\min ^{-1}$ plot $^{-1}$ ) & $15.6 \pm 10.9$ & $40.7 \pm 7.2$ & $70.5 \pm 33.1$ & 0.046 \\
\hline \multicolumn{2}{|l|}{ Acanthurid total } & & & ${ }^{*} 25 \% \mathrm{~T}>\mathrm{C}$ \\
\hline Abundance $\left(25 \mathrm{~m}^{-2}\right)$ & $0.9 \pm 0.6$ & $1.1 \pm 0.3$ & $1.6 \pm 0.1$ & 0.185 \\
\hline Total bites (bites min $^{-1}$ plot $^{-1}$ ) & $24.7 \pm 16.5$ & $47.5 \pm 6.3$ & $77.4 \pm 28.8$ & 0.044 \\
\hline \multicolumn{2}{|l|}{ Scarid total } & & & \\
\hline Abundance $\left(25 \mathrm{~m}^{-2}\right)$ & $3.0 \pm 0.8$ & $2.8 \pm 0.8$ & $3.3 \pm 1.2$ & 0.804 \\
\hline Total bites (bites min $^{-1}$ plot $^{-1}$ ) & $83.2 \pm 22.5$ & $69.8 \pm 34.2$ & $92.4 \pm 33.9$ & 0.680 \\
\hline \multicolumn{2}{|c|}{ Acanthurid and scarid } & & & \\
\hline \multicolumn{2}{|c|}{ Total bites (bites min $^{-1}$ plot $^{-1}$ ) $107.9 \pm 35.2$} & $117.3 \pm 27.9$ & $169.8 \pm 58.9$ & 0.241 \\
\hline
\end{tabular}

bivorous fish was greater in $25 \% \mathrm{~T}$ plots than in control plots in the later stages of the experiment (specifically of scarids in Month 3 and acanthurids in Month 5, Fig. 4). Our subjective impression, however, was that grazing fishes were initially scarcer in tiled plots than in control plots, and it was only after substantial alterations to benthic algal communities were well under way in $25 \% \mathrm{~T}$ plots that those areas became more attractive to grazing fishes. Evidence of fish censuses tends to support that view as (1) it was not until the 2nd census, 3 mo after tiles were placed, that there were any significant differences between $25 \% \mathrm{~T}$ and control plots in terms of biomass of scarids or acanthurids (Fig. 4); and (2) there was no evidence that herbivore biomass was greater in $10 \% \mathrm{~T}$ plots than in control plots at any time during the experiment (Fig. 4), in spite of which mean macroalgal cover was

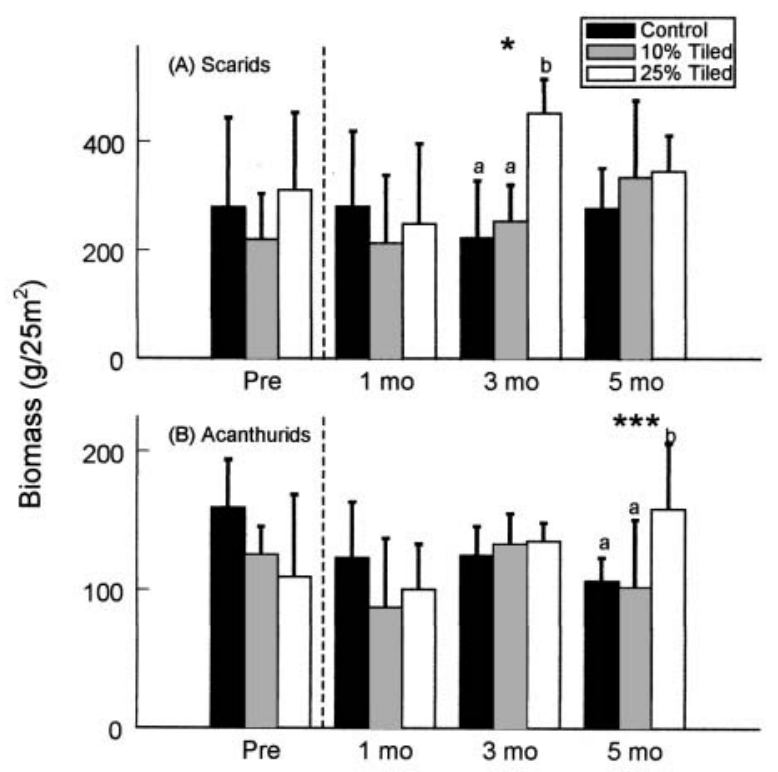

Fig. 4. Mean biomass of (A) scarids and (B) acanthurids in treatments at each survey period. Broken vertical line and $x$-axis labels as for Fig. 2. Error bars indicate \pm 1 SD (data were pooled into averages per plot before calculation of mean and $\mathrm{SD}$ and therefore $\mathrm{n}=3$ in each case). ${ }^{*} \mathrm{p}<0.05_{i}{ }^{* * *} \mathrm{p}<0.005$ significant differences among groups at any survey period. Letters attached to bars indicate groups that did not differ significantly (Tukey's pairwise comparisons)

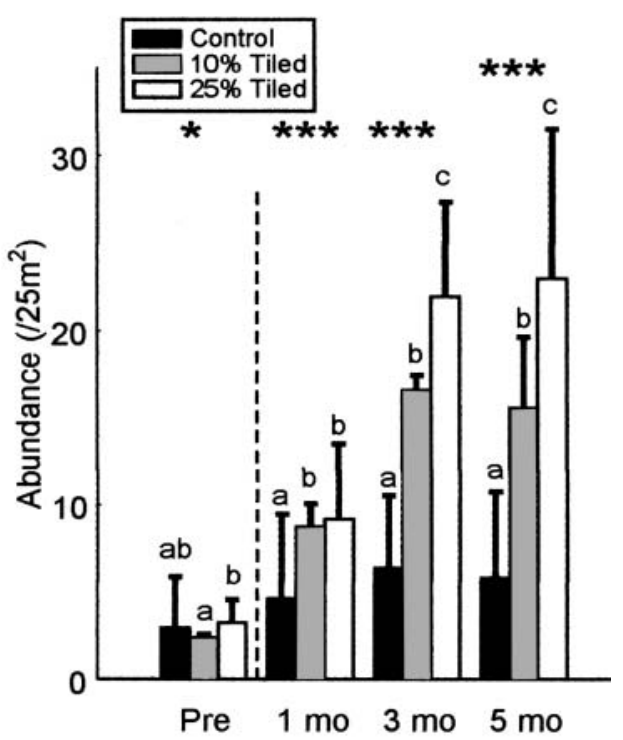

Fig. 5. Mean abundance of pomacentrids in experimental groups. Broken vertical line and column labels as for Fig. 2. Error bars indicate $\pm 1 \mathrm{SD}$ (data were pooled into averages per plot before calculation of mean and SD and therefore $\mathrm{n}=3$ in each case). ${ }^{*} \mathrm{p}<0.05{ }_{i}{ }^{* * *} \mathrm{p}<0.005$, significant differences among groups at any survey period. Letters attached to bars indicate groups that did not differ significantly within survey periods (Tukey's pairwise comparisons) 
significantly lower in $10 \% \mathrm{~T}$ plots $(28.7 \%)$ than in control plots $(38.0 \%)$ over the last 3 mo of the experiment (Fig. 3). Grazing surveys were conducted in Month 5 (October 1999) by which time differences among groups in the functional composition of benthic algal communities were well established. In spite of those differences, scarid feeding rate (bites $\mathrm{min}^{-1}$ fish $^{-1}$ ) and total grazing pressure in plots (bites $\mathrm{min}^{-1}$ plot $^{-1}$ ) did not differ among experimental groups (Table 2), suggesting that placing tiles within plots had little impact on the grazing behaviour of scarids. In contrast, feeding rate and grazing pressure of the dominant acanthurid, the ocean surgeonfish Acanthurus bahianus, were significantly higher in $25 \% \mathrm{~T}$ than in control plots (Table 2). We assume that this was a response to improved grazing conditions in plots with comparatively low macroalgal cover (McClanahan et al. 1999b) rather than being a significant cause of macroalgal declines in the first place.

Placing tiles within plots led to a 3 - to 4 -fold increase in density of the pomacentrid Stegastes partitus (Fig. 5). This was probably a response to the large number of small hiding places under tiles that were not completely flush with the reef substrate. De Ruyter van Steveninck (1984) found no difference in terms of biomass or diversity between algal communities inside and outside of $S$. partitus territories, and similarly we think it unlikely that they had a large impact on benthic algae in plots. The impact of grazing by $S$. partitus was probably negligible as, even after local increases in density, they comprised a very small proportion of total herbivore biomass $(<5 \%)$ and in any case they appeared to feed predominantly on pelagic rather than benthic algae (I. D. Williams pers. obs., Emery 1973, Nemeth 1998). If anything, the effect of increases in pomacentrid density would be to reduce grazing intensity within tiled plots as territorial defence might deter grazing by other herbivorous fishes. However, we believe that the effects of territorial defence were probably not substantial as $S$. partitus is a small pomacentrid and only appeared to defend territories against juvenile scarids and acanthurids. Even then, actual charges or attacks were rare and, generally, attacked fishes moved only a short distance away and rapidly resumed feeding (I. D. Williams pers. obs.).

For practical reasons, the spatial and temporal scale of the experiment were rather small (i.e., $5 \times 5 \mathrm{~m}$ plots monitored for $5 \mathrm{mo}$ at 1 location) and the experiment took no account of any of the longer-term changes that might follow alterations in coral and algal community structure. In particular, it is not clear from this experiment what the likely longer-term effects on herbivorous fish populations and therefore grazing potential would be. The likelihood though is that rising coral cover would be accompanied by increased 3-dimen- sional complexity of reef structure, which in turn would probably increase the reef's capacity to support large and diverse herbivorous fish population (Risk 1973, Roberts \& Ormond 1987, Szmant 1997). Therefore, a degree of caution should be applied when extrapolating the results of this study to the wider problem of macroalgal overgrowth of Caribbean reefs. Nevertheless, these results do provide support for the concept of an upper threshold of substratum that can be cropped down by herbivorous fishes on reefs at this depth and are consistent with our large-scale correlative work (Williams \& Polunin 2001).

Clearly, the concept of an upper threshold to grazing by herbivorous fishes that is implied by the model (Fig. 1) is a simplistic one. It is not our intention to imply that there are rigidly fixed or precisely predictable limits to grazing by herbivorous fishes on Caribbean reefs at this depth. In fact, the considerable short-term variability in the functional composition of benthic algal communities even in unmanipulated plots clearly argues against the idea of a fixed threshold (e.g., mean cover of cropped substrata in control plots varied between 46 and $68 \%$ over the 6 mo of the experiment, Fig. 2). We attribute that short-term variability to seasonal differences in algal growth rates, grazing rates, and the amount of scouring or other inhibition of algae during stormy weather (Aronson et al. 1994, Rogers et al. 1997). Among widely separated reefs and over extended time periods, there would inevitably be large differences in other factors affecting algal growth and succession such as sediment regime (McClanahan 1997) and nutrient supply (Cronin \& Hay 1996), and in the carrying capacity and population structure of herbivorous fishes, driven by variability in factors such as microhabitat availability (Tolimieri 1998) and reef structural complexity (Risk 1973, Roberts \& Ormond 1987). However, a reasonable broad generalisation is that the amount of substratum occupied by algae on high coral-cover reefs is within the range that can be cropped down by existing populations of herbivorous fishes, but, as coral cover is lost and replaced by algae on degrading reefs, and in the continuing absence of Diadema, then at some point the amount of substratum occupied by algae will probably overwhelm the ability of resident herbivorous fishes to crop it down. In such circumstances, stands of macroalgae can be expected to develop and tend to persist, perhaps further reinforcing the shift towards macroalgal domination by overgrowing corals and substratum and thereby adversely affecting growth, fecundity, and recruitment of corals (Tanner 1995, Hughes 1996).

The inability of herbivorous fishes to crop down the large amount of substratum occupied by algae on lowcover reefs raises the question of how important the 
loss of Diadema has generally been on reefs at this depth. Even before the Diadema die-off, urchin densities were ordinarily rather low on mid-depth and deeper reefs, certainly much lower than in shallow water (Lewis \& Wainwright 1985, de Ruyter van Steveninck \& Breeman 1987, Morrison 1988, Jackson 1991). Nevertheless, urchin grazing apparently played an important role in preventing establishment of macroalgae on mid-depth reefs in at least some locations. For example, Liddel \& Ohlhorst (1992) reported Diadema density in August 1982 of $6.4 \mathrm{~m}^{-2}$ on a $15 \mathrm{~m}$ deep forereef site in Discovery Bay, Jamaica. Two years later (after the die-off) urchins were absent at this depth, and mean macroalgal cover had increased from $20.5 \%$ to $56.9 \%$. Diadema were evidently also present even on some lightly fished deeper reefs; for example, de Ruyter van Steveninck \& Breeman (1987) reported that before the mass mortality event Diadema were 'abundant' at $12 \mathrm{~m}$ deep and 'present' down to $30 \mathrm{~m}$ on 1 of their study reefs in Curaçao. After the loss of Diadema grazing from these deeper reefs, the abundance of the macroalga Lobophora increased from 'present' to 'patchy'. Conceivably, therefore, urchins might generally have been important grazers on mid-depth reefs with low coral cover.

It should also be noted that the results of this study, from a $12 \mathrm{~m}$ deep site, and our large-scale correlative work, based on a number of 12 to $15 \mathrm{~m}$ deep reefs (Williams \& Polunin 2001), are not directly generalisable to reefs at other depths. On Caribbean reefs, grazer densities tend to be greatest in shallow water and decline with depth (Hay 1981, Hay et al. 1983, de Ruyter van Steveninck \& Breeman 1987, Morrison 1988), and, therefore, although that may be offset to some extent by greater algal productivity in shallow water (Hay et al. 1983), the likelihood is that herbivore populations in shallower water would generally be able to crop down larger amounts of substratum. Certainly, in some circumstances, grazing by herbivorous fish alone can be sufficient to virtually exclude macroalgae from shallow reefs with very low coral cover (Lewis 1986, Bruggemann et al. 1994).

The few published studies of mid-depth Caribbean reefs from the early 1980s and before generally report coral cover to be 30 to $60 \%$ (Dustan \& Halas 1987, Liddel \& Ohlhorst 1992, Porter \& Meier 1992). More recent reports indicate that coral cover is now typically $20 \%$ or less on Caribbean reefs at this depth (Aronson et al. 1994, Rogers et al. 1997, Williams \& Polunin 2001). It is therefore at least plausible that declining coral cover has widely contributed to rises in macroalgal domination, at least on mid-depth reefs, and similarly that any future increases in coral cover would tend to reverse such rises in macroalgal cover.
Acknowledgements. Logistic support and permission to undertake the work were provided by Miguel Alamilla (Hol Chan Marine Reserve, Belize) and James Azueta (Department of Fisheries, Belize). James Guest, Ineke Wesseling, Mark Reynolds, and Kim Last assisted substantially with field work. We are particularly grateful for the assistance of the owners and staff of Amigos Del Mar dive shop in San Pedro, Belize.

\section{LITERATURE CITED}

Aronson RB, Precht WF (1997) Stasis, biological disturbance, and community structure of a Holocene coral reef. Paleobiology 23:326-346

Aronson RB, Precht WF (2000a) Herbivory and algal dynamics on the coral reef at Discovery Bay, Jamaica. Limnol Oceanogr 45:251-255

Aronson RB, Precht WF (2000b) White band disease and the changing face of Caribbean coral reefs. Hydrobiologia (in press)

Aronson RB, Edmunds PJ, Precht WF, Swanson DW, Levitan DR (1994) Large-scale, long-term monitoring of Caribbean coral reefs: simple, quick, inexpensive techniques. Atoll Res Bull 421:19

Aronson RB, Precht WF, Macintyre IG, Murdoch TJT, Edmunds PJ, Swanson DW, Levitan DR (2000) Ecosystems — coral bleach-out in Belize. Nature 405:36-36

Bohnsack JA, Harper DE (1988) Length-weight relationships of selected marine fishes from the southeastern United States and the Caribbean. NOAA technical report NMFSSEFC, 215. National Oceanic and Atmospheric Administration, Washington, p 31

Bruggemann JH, van Oppen MJH, Breeman AM (1994) Foraging by the stoplight parrotfish Sparisoma viride. I. Food selection in different socially determined habitats. Mar Ecol Prog Ser 106:41-55

Carpenter RC (1990) Mass mortality of Diadema antillarum. I. Long-term effects on sea urchin population-dynamics and coral reef algal communities. Mar Biol 104:67-77

Connell JH (1997) Disturbance and recovery of coral assemblages. Coral Reefs 16:S101-113

Cronin G, Hay ME (1996) Effects of light and nutrient availability on the growth, secondary chemistry, and resistance to herbivory of two brown seaweeds. Oikos 77: 93-106

de Ruyter van Steveninck ED (1984) The composition of algal vegetation in and outside damselfish territories on a Florida reef. Aquat Bot 20:11-19

de Ruyter van Steveninck ED, Breeman AM (1987) Deep water vegetations of Lobophora variegata (Phaeophyceae) in the coral reef of Curaçao: population dynamics in relation to mass mortality of the sea-urchin Diadema antillarum. Mar Ecol Prog Ser 36:81-90

Doherty PJ, Williams DM (1988) The replenishment of coral reef fish populations. Oceanogr Mar Biol Annu Rev 26: 487-551

Dustan P, Halas JC (1987) Changes in the reef-coral community of Carysfort Reef, Key Largo, Florida -1974 to 1982. Coral Reefs 6:91-106

Emery AR (1973) Comparative ecology and functional osteology of fourteen species of damselfish (Pisces: Pomacentridae) at Alligator Reef, Florida Keys. Bull Mar Sci 23: $649-770$

Hay ME (1981) Spatial patterns of grazing intensity on a Caribbean barrier reef: herbivory and algal distribution. Aquat Bot 11:97-109

Hay ME, Colurn T, Downing D (1983) Spatial and temporal 
patterns of herbivory on a Caribbean fringing reef: the effects on plant distribution. Oecologia 58:299-308

Hixon MA (1991) Predation as a process structuring coral reef fish communities. In: Sale PF (ed) The ecology of fishes on coral reefs. Academic Press, San Diego, p 475-508

Hughes TP (1994) Catastrophes, phase shifts, and large-scale degradation of a Caribbean coral reef. Science 265: $1547-1551$

Hughes TP (1996) Demographic approaches to community dynamics: A coral reef example. Ecology 77:2256-2260

Jackson JBC (1991) Adaptation and diversity of reef corals. Bioscience 41:475-482

Lapointe BE (1997) Nutrient thresholds for bottom-up control of macroalgal blooms on coral reefs in Jamaica and southeast Florida. Limnol Oceanogr 42:1119-1131

Lapointe BE, Littler MM, Littler D (1992) Modification of benthic community structure by natural eutrophication: the Belize Barrier Reef. In: Proc 7th Int Coral Reef Symp, Guam 1: 323-334

Lessios HA (1988) Mass mortality of Diadema antillarum in the Caribbean: what have we learned? Annu Rev Ecol Syst 19:371-393

Levitan DR (1988) Algal-urchin biomass responses following mass mortality of Diadema antillarum Philippi at Saint John, US Virgin Islands. J Exp Mar Biol Ecol 119:167-178

Lewis SM (1986) The role of herbivorous fishes in the organization of a Caribbean reef community. Ecol Monogr 56: $183-200$

Lewis SM, Wainwright PC (1985) Herbivore abundance and grazing intensity on a Caribbean coral reef. J Exp Mar Biol Ecol 87:215-228

Liddel WD, Ohlhorst SL (1986) Changes in benthic community composition following the mass mortality of Diadema antillarum. J Exp Mar Biol Ecol 95:183-200

Liddel WD, Ohlhorst SL (1992) Ten years of disturbance and change on a Jamaican fringing reef. In: Proc 7th Int Coral Reef Symp, Guam 1:144-150

Littler MM, Taylor PR, Littler DS, Sims RH, Norris JN (1987) Dominant macrophyte standing stocks, productivity and community structure on a Belizian barrier reef. Atoll Res Bull 302:1-24

McClanahan TR (1997) Primary succession of coral-reef algae: differing patterns on fished versus unfished reefs. J Exp Mar Biol Ecol 218:77-102

McClanahan TR, Muthiga NA (1998) An ecological shift in a remote coral atoll of Belize over 25 years. Environ Conserv 25:122-130

McClanahan TR, Aronson RB, Precht WF, Muthiga NA

Editorial responsibility: Otto Kinne (Editor),

Oldendorf/Luhe, Germany (1999a) Fleshy algae dominate remote coral reefs of Belize. Coral Reefs 18:61-62

McClanahan TR, Hendrick V, Rodrigues MJ, Polunin NVC (1999b) Varying responses of herbivorous and invertebrate-feeding fishes to macroalgal reduction on a coral reef. Coral Reefs 18:195-203

Morrison D (1988) Comparing fish and urchin grazing in shallow and deeper coral reef algal communities. Ecology 69:1367-1382

Nemeth RS (1998) The effect of natural variation in substrate architecture on the survival of juvenile bicolor damselfish. Environ Biol Fish 53:129-141

Polunin NVC, Roberts CM (1993) Greater biomass and value of target coral-reef fishes in two small Caribbean marine reserves. Mar Ecol Prog Ser 100:167-176

Porter JW, Meier OW (1992) Quantification of loss and change in Floridian reef coral populations. Am Zool 32:625-640

Risk MJ (1973) Fish diversity on a coral reef in the Virgin Islands. Atoll Res Bull 153:1-16

Roberts CM, Ormond RFG (1987) Habitat complexity and coral-reef fish diversity and abundance on Red-Sea fringing reefs. Mar Ecol Prog Ser 41:1-8

Rogers CS, Garrison V, Grober-Dunsmore R (1997) A fishy story about hurricanes and herbivory: seven years of research on a reef in St. John, US Virgin Islands. In: Proc 8th Int Coral Reef Symp, Panama 1:555-560

Shulman MJ, Robertson DR (1996) Changes in the coral reefs of San Blas, Caribbean Panama: 1983 to 1990. Coral Reefs 15:231-236

Szmant AM (1997) Nutrient effects on coral reefs: a hypothesis on the importance of topographic and trophic complexity to reef nutrient dynamics. In: Proc 8th Int Coral Reef Symp, Panama 2:1527-1532

Tanner JE (1995) Competition between scleractinian corals and macroalgae: an experimental investigation of coral growth, survival and reproduction. J Exp Mar Biol Ecol 190:151-168

Tolimieri N (1998) Contrasting effects of microhabitat use on large-scale adult abundance in two families of Caribbean reef fishes. Mar Ecol Prog Ser 167:227-239

van Rooij JM, Kok JP, Videler JJ (1996) Local variability in population structure and density of the protogynous reef herbivore Sparisoma viride. Environ Biol Fish 47:65-80

Williams EHJ, Bunkley-Williams L (1990) The world-wide coral reef bleaching cycle and related sources of coral mortality. Atoll Res Bull 355:1-72

Williams ID, Polunin NVC (2001) Large-scale associations between macroalgal cover and grazer biomass on middepth reefs in the Caribbean. Coral Reefs 19(4):358-366

Submitted: August 8, 2000; Accepted: February 1, 2001

Proofs received from author(s): October 16, 2001 